\title{
Dermatolojik hastalıkların tedavisinde immunmodülasyon
} Immunmodulation in the treatment of dermatological diseases

\section{Özet}

Dermatolojide kullanılan topikal ya da sistemik tedavilerin çok büyük bir kısmının, hatta fiziksel tedavi yöntemlerinin bile etki mekanizmaları arasında immünolojik etkiler önemli yer tutmaktadır. Bu etkiler, tedavi edilen hastalığa göre değişmek üzere, immun sistemin baskılanması ya da stimüle edilmesi veya mevcut fonksiyonların değiştirilmesi yönünde olabilir. Bu makalede, dermatolojik hastalıkların tedavisindeki etkilerini başılıca immunmodülasyon yoluyla gösteren ilaçlar anlatılmaktadır. Makalede yer alan tedavi seçenekleri azatiyoprin, mikofenolat mofetil, siklosporin, glukokortikosteroidler, topikal kalsinörin inhibitörleri, foto(kemo)terapi, intravenöz immunglobulin, interferon, rituksimab, omalizumab, imiquimod ve ekstrakorporeal fotoferez, özellikle immunmodülasyon yönündeki etkilerini vurgulayan bir bakış açısılla anlatılmış, bu ajanların kullanım şekillerine, tedavi protokollerine, tedavi sırasında monitörizasyon konusundaki önemli noktalara yer verilmemiştir. (Türkderm 2013; 47: Özel Sayı 1: 46-51)

Anahtar Kelime: Immunmodülasyon, dermatoloji, tedavi

\section{Summary}

Immunological effects have an important role in the action mechanisms of the majority of topical and systemic agents, and even some physical treatment modalities in dermatology. Depending on the disease being treated, these effects may be suppression or stimulation of the immune system as well as modulation of the existing functions. Agents that show their effects mainly by immunmodulation in the treatment of dermatological diseases are discussed in the present article. Treatment alternatives included in the article, azathioprine, mycophenolate mofetil, cyclosporine, glucocorticosteroids, topical calcineurin inhibitors, photo(chemo)therapy, intravenous immunoglobuline, interferon, rituximab, omalizumab, imiquimod and extracorporeal photopheresis are discussed focusing especially on their immunomodulatory effects without any mention on their prescribing details, treatment protocols and monitorization aspects. (Turkderm 2013; 47: Suppl 1: 46-51)

Key Words: Immunomodulation, dermatology, treatment

\section{Giriş}

İmmun sistem, dermatolojik hastalıkların pek çoğunun patogenezinde önemli rol oynamaktadır. Dermatolojide kullanılan tedaviler, hastalık patogenezinde ön planda yer alan immünolojik mekanizmaları hedef alarak etki gösterebilmektedir. Bu etki, tedavi edilen hastalığa göre değişmek üzere, immun sistemin baskılanması ya da stimüle edilmesi veya mevcut fonksiyonların değiştirilmesi yönünde olabilir. Aslında dermatolojide kullanılan topikal ya da sistemik tedavilerin çok büyük bir kısmının, hatta fiziksel tedavi yöntemlerinin bile etki mekanizmaları arasında immünolojik etkiler önemli yer tutmaktadır. $\mathrm{Bu}$ makalede, dermatolojik hastalıkların tedavisindeki etkilerini başlıca immunmodülasyon yoluyla gösteren ilaçlar anlatılmaktadır. Ancak, immunmodülasyon, değişen derecede, pek çok dermatolojik tedavi ajanı için geçerli bir etki mekanizması olduğundan, bu makale, bu tedavilerin tümünü kapsamamaktadır. Ayrıca makalede yer alan tedavi seçenekleri, özellikle immunmodülasyon yönündeki etkilerini vurgulayan bir bakış açısıyla anlatılmış, kullanım şekilleri, yan etkileri, monitörizasyon gibi konulara ayrıntılı yer verilmemiştir.

Yazışma Adresi/Address for Correspondence: Dr. Dilek Seçkin, Marmara Üniversitesi Tıp Fakültesi, Deri ve Zührevi Hastalıklar Anabilim Dalı, İstanbul, Türkiye Tel.: +90 21665706 06/4648 E-posta: seckin_dilek@yahoo.com 


\section{Azatiyoprin}

Dermatolojide en sık kullanılan immunsupresif ajanlardan biridir. 1960'ı yıllardan beri farklı endikasyonlarda reçete edilen bir ilaç olmasına rağmen1, güncelliğini halen korumaktadır. Azatiyoprin, aslında bir ön ilaç olup, oral yolla alındıktan sonra 6-merkaptopurine dönüşür. 6-merkaptopurin, biri tiyopurinmetiltransferaz (TPMT), diğeri ksantin oksidaz olmak üzere 2 farklı enzim tarafından, sırasıyla, 6-metilmerkaptopurin ve 6-tiyourik asite dönüştürülerek inaktive edilir. 6-merkaptopurinin inaktif metabolitlerine dönüşmesinde bir defekt olması durumunda, tiyopurin metabolizmasının aktif metabolitleri olan tiyoguanin nükleotidleri fazla miktarda oluşur ve çeşitli toksik etkiler ortaya çıkar. İnaktivasyon yolağındaki defektin temel sebebi ise, TPMT aktivitesinde genetik olarak belirlenen varyasyonlardır1-3. TPMT aktivitesinde artış, metabolizmanın inaktivasyon yönünde ilerlemesine yol açacağından, yeterli etkinlik için azatiyoprin dozunun artırıması gereksinimi doğar. Buna karşıllk, TPMT aktivitesinde azalma, tiyoguanin nükleotidlerinin artışına ve enzim aktivitesinde azalmanın derecesine bağlı olarak değişen derecede, başta miyelosupresyon olmak üzere çeşitli yan etkilerin ortaya çıkmasına sebep olur4-6. Azatiyoprinin aktif metaboliti olan 6-tiyoguanin bir pürin analoğudur. Azatiyoprin, DNA, RNA ve protein sentezini inhibe eder. Langerhans hücrelerinin sayısını ve antijen sunma özelliklerini azaltır. $T$ lenfosit fonksiyonlarını ve $B$ lenfositlerinin antikor oluşumunu baskılar2,7,8. Immunsupresif özelliği dışında antiinflamatuar etkileri de olan azatiyoprinin7 dermatolojideki kullanım alanı oldukça geniştir. Pemfigus vulgaris ve büllöz pemfigoid, lupus eritematozus, dermatomiyozit, şiddetli atopik dermatit ve kronik aktinik dermatit gibi dirençli dermatitler, Wegener granülomatozisi ve diğer vaskülitler, Behçet hastalığı ve piyoderma gangrenozum gibi hastalıklarda etkinliği bilinmektedir ${ }^{1}$. Başııca yan etkileri miyelotoksisite hepatotoksisite ve bulantıdır. Uzun süreli immunsupresyona sebep olması nedeniyle, infeksiyon ve neoplazi riskinde artış ile ilişkili bir ajandır 1-3,7.

\section{Mikofenolat mofetil}

Mikofenolat mofetil, dermatolojide kullanım alanı açısından azotiyoprin ile oldukça benzerlik gösterir. 1995 yllında FDA (Food and Drug Administration) tarafından böbrek ve karaciğer transplantasyonunda allogreft reddini önlemek amacıyla kullanımı onaylanmış bir immunsupresiftir9. Oral olarak alındıktan sonra, plazma esteraz aracılığıyla, aktif metaboliti olan mikofenolik asite dönüşür. Mikofenolik asit, de novo pürin sentezinde anahtar rol oynayan bir enzim olan inozin monofosfat dehidrogenazı inhibe eder. Bu enzimin inhibisyonu ise, DNA ve RNA sentezi için önemli bir substrat olan guanozin monofosfatın oluşmasına engel olur. T ve B lenfositleri, pürin sentezi için de novo yola bağımlı iken, başka hücrelerde salvaj yolla da pürin sentezi gerçekleşebilir9-11. Mikofenolat mofetilin spesifik olarak T ve B lenfositlerinin proliferasyonunu engellemesi, bu ilaçla istenmeyen yan etkilerin azatiyoprine oranla daha az görülmesinin temel sebebidir. Mikofenolat mofetilin lenfositler üzerindeki sitostatik etkilerinin yanısıra, antikor oluşumunu baskılama, lenfosit ve monositlerin endotele adezyonunu azaltarak lökositlerin inflamasyon alanına toplanmasını engelleme, gecikmiş tipte hipersensitivite reaksiyonlarını baskılama gibi etkileri de bulunmaktadır7,12. Mikofenolat mofetil, azatiyoprin gibi, immunsupresif etkilerinin yanısıra antiinflamatuar özelliklere de sahip bir ilaçtır?.

Mikofenolat mofetilin dermatolojide kullanıldığı başlıca hastalıklar, otoimmün büllü hastalıklar, dermatitler, lupus eritematozus, dermatomiyozit, çeşitli vaskülitler, psoriasis ve greft-versus-host hastalığıdır9 ${ }^{9}$. En sık görülen yan etkileri gastrointestinal yan etkiler olup, miyelotoksisitesi nadirdir2,3,9,10. Azatiyoprin ve mikofenolat mofetilin pürin sentez inhibisyonu şeklindeki temel etki mekanizmaları, bu iki ilacın dermatolojide ortak kullanım alanına sahip olmasına yol açmaktadır. Mikofenolat mofetilin lenfositlere spesifik etkisi ise, bu ajanı, azatiyoprine göre daha az yan etkiye sahip bir seçenek haline getirmektedir. Mikofenolat mofetil, azatiyoprinden daha pahalı bir ilaçtır.

\section{Siklosporin}

Siklosporin, selektif olarak T lenfositlere etkili olduğu gösterilmiş ilk immunsupresif ajandır. 1983 yılında FDA tarafından transplant reddinin önlenmesi için, 1997 yılında ise psoriasiste kullanımı onaylanmıştır13. Antijen sunumu sırasında, antijen sunucu hücre ile T lenfosit etkileşimi sonucu ortaya çıkan T hücre reseptör aktivasyonu, hücre içinde kalsiyum artışına sebep olur. Artan kalsiyum kalmoduline bağlanır ve bu kompleks, kalsinörini aktive eder. Kalsinörin-kalmodulin kompleksi, aktive T hücre nükleer faktörünün sitoplazmik kısmını (NFaTc) defosforile ederek NFaTc'nin nukleus içine girmesine sebep olur. NFaTc, nukleus içinde, aktive $T$ hücre nükleer faktörünün nukleer kısmı ile birleşerek NFaTcNFaTn kompleksini oluşturur. Bu kompleks, interlökin (IL) 2 başta olmak üzere, IL-3, IL-4, TNF- $\alpha$ ve IFN- $\gamma$ gibi sitokinler için bir transkripsiyon faktörü olarak görev yapar. Siklosporin, intrasitoplazmik bir protein olan siklofilin ile bağlanarak, kalsinörin fosfatazı inhibe eder. Böylece NFaTc defosforile olamaz ve nukleus içine giremez 7,13 . IL-2 ve diğer sitokinlerin transkripsiyonu gerçekleşemez. Siklosporin, bu şekilde, epidermis ve dermisteki lenfosit ve makrofajların azalmasını sağlar, T hücreler, doğal öldürücü (NK) hücreler ve antijen sunucu hücrelerin aktivasyonunu inhibe eder. Ayrıca keratinosit proliferasyonunu ve mast hücrelerinden histamin salınımını inhibe eder, endotel yüzeyindeki adezyon moleküllerinin ekspresyonunu ve $T$ lenfosit ve nötrofil infiltrasyonunu azaltır13-15. Siklosporinin dermatolojideki başlıca kullanım alanı, T lenfositlerin patogenezde önemli rol oynadığı hastalıklardır. Bunlar içinde psoriasis, atopik dermatit, prurigo nodularis, kronik ürtiker, piyoderma gangrenozum, dermatomiyozit, fotodermatozlar, paraneoplastik pemfigus, liken planus ve alopesi areata sayılabilir13,16,17. Başıca yan etkileri hipertansiyon ve neftotoksisite olup, siklosporin kullanımı sırasında ilaç etkileşimleri konusunda özellikle dikkatli olmak gereklidir.

\section{Glukokortikosteroidler}

Glukokortikosteroidler (GKS) temel olarak antiinflamatuar özellikleri ile çok geniş kullanım alanına sahip ajanlardır. 1950 yılında Hench ve arkadaşları, GKSlerin etkileri ve toksisiteleri üzerine yaptıkları çalışmaları ile Nobel ödülü almışlardır ${ }^{18}$. GKS, sitoplazmik reseptörüne bağlandıktan sonra nukleus içine transloke olur. GKS'lerin etki mekanizmaları içerisinde, NF-кB inhibisyonu ve inflamatuar yanıtın baskılanması, intrasellüler adezyon molekülü 1 ve E-selektin gibi adezyon moleküllerinin inhibisyonu, nitrik oksit sentaz, siklooksijenaz ve fosfolipaz gibi inflamatuar enzimlerle birlikte, TNF- $\alpha$, GM-CSF, IL-1, IL-2, IL-6, IL-8 gibi çeşitli sitokinlerin sekresyonunda azalma sayılabilir19. GKSlerin etkisiyle kemik iliğinden nötrofillerin dolaşıma geçmesi sonucu nötrofili ortaya çıkar, ancak, adezyon molekülleri ve kemoattraktanların da inhibisyonu nedeniyle, nötrofiller inflamasyon alanına göç edemez20. GKS'lerin diğer etkileri arasında, IL-2'nin azalması nedeniyle $T$ hücre aktivasyonunda inhibisyon, dendritik hücreler tarafından $T$ hücrelerine antijen sunumunda azalma, dolaşımda yer alan eozinofillerin sayısında azalma yer almaktadır 19,21. 
B hücre fonksiyonu inhibisyonu ise ancak yüksek dozlarda GKS verilmesi ile ortaya çıkmakta olup19 özellikle pemfigus vulgariste pulse steroid tedavisi başlıca bu mekanizmayla etkili olur. GKS'ler, immunsupresif, immunmodulatuar ve antiinflamatuar özellikleri aynı anda barındıran ve hedefe özgü olmayan etki mekanizmaları nedeniyle, patogenezleri farklı pek çok hastalığın tedavisinde kullanılmaktadır. Bu hedefe yönelik olmayan etkiler, özellikle uzun süreli kullanımda pek çok sistemi ilgilendirebilen yan etkilerin de ortaya çıkmasıyla ilişkilidir.

\section{Topikal kalsinörin inhibitörleri}

Oral takrolimus, transplant hastalarında uzun yıllardır kullanılmakta olan immunsupresif bir ilaçtır. Topikal takrolimus ve pimekrolimus, başlıca atopik dermatit olmak üzere steoidlerin etkili olduğu çeşitli hastalıkların tedavisinde kullanılan makrolaktam immunmodulatuar ajanlardır. Etkilerini, sitoplazmik makrofilin reseptörüne bağlanarak gösterirler. Makrofilin ile oluşturdukları kompleks, siklosporin-siklofilin kompleksine benzer şekilde, kalsinörini inhibe ederek, yukarıda bahsedildiği gibi çeşitli sitokinlerin ekspresyonunun azalmasına yol açar. IL-2, IL-4, IL-10 ve IFN- $\gamma$ gibi proinflamatuar sitokinlerin ve $T$ hücre proliferasyonunun inhibisyonu, epidermal dendritik antijen sunucu hücrelerin yapısında ve fonksiyonunda değişiklik ve mast hücrelerinden histamin salınımında inhibisyon, topikal kalsinörin inhibitörlerinin etkileri arasındadır22-24.

\section{Foto(kemo)terapi}

Ultraviyole (UV) ışınlarının dermatolojik hastalıkların tedavisinde kullanım öyküsü çok eski yıllara dayanır. Niels Ryberg Finsen, yapay UV ışınları ile lupus vulgarisi tedavi ederek, bu buluşuyla 1903 yılında Nobel ödülü kazanmıştır. Finsen, günümüze kadar dermatoloji alanında Nobel ödülü almış tek kişidir. 1923 yılında Goeckerman rejimi (UVB + katran), 1970'li yıllarda psoralen ve UVA (PUVA) tedavisi tanımlanmış, 1984 yılında ise dar bant UVB'nin psoriasisteki etkinliği ile ilgili ilk makale yayınlanmıştır25. UV ışınlarının çeşitli deri hastalıklarının tedavisindeki başarısından temel olarak immunsupresif etkileri sorumludur. UV ile indüklenen immunsupresyonu araştırmak için en iyi model, kontakt hipersensitivite indüksiyonunun supresyonu modelidir26. Potent kontakt allerjenlerin topikal olarak uygulanması sonrası birkaç gün sonra antijene spesifik sensitizasyon ortaya çıkar. Daha önce UV ışınlarına maruz kalmış deriye aynı kontakt allerjenin uygulanması durumunda ise sensitizasyon ortaya çıkmaz. Bunun sebebi, UV etkisi ile meydana gelen ve uzun süreli olan antijene spesifik immuntoleranstır. İmmuntolerans, UV ile indüklenen, antijene spesifik CD4 ve CD25 pozitif T regulatuar hücreler aracılığılla ortaya çıkmaktadır26-28. UV ile indüklenen immunsupresyon için asıl tetikleyici faktör, siklobütan pirimidin dimerleri ve 6-4 fotoürünlerin oluşumu ve DNA hasarıdır29.

\section{İntravenöz immunglobulin}

İlk kez kullanıldığı 1980'li yıllardan beri intravenöz immunglobülin (IVIG) tedavisinin kullanım alanları her geçen gün artmaktadır. Hem immunreplasman, hem immunmodülasyon hem de inflamasyonu baskılamak amacı ile kullanılmaktadır. 1000-15000 arası vericiden alınan plazma havuzundan elde edilir. Saflaştııımış immunglobülini stabilize etmek amacı ile glikoz, maltoz, sükroz, mannitol, sorbitol, glisin ya da albumin gibi ajanların genelde eklenmesi gerekmektedir. Immünglobülin oranının \%90'ından fazlasını lgG oluşturur. iki $\mathrm{gr} / \mathrm{kg}$ dozunda IViG infüzyonu yapıldığında serum IgG seviyesi yaklaşık 5 kat $\operatorname{artar30}$. Dermatolojide geniş kullanım yeri bulan iviG tedavisi Kawasaki hastalığı, otoimmun büllöz hastalıklar, ürtiker, hipereozinofilik hastalıklar, skleromiksödem, toksik epidermal nekroliz, atopik dermatit, pretibyal miksödem, konnektif doku hastalıkları, nefrojenik fibrozan dermopati, piyoderma gangrenosum, Behçet hastalığı ve diğer vaskülitler, yaygın viral siğiller, polimorf ışık erüpsiyonu gibi hastalıklarda kullanılmıştır31-35. Dermatolojik endikasyonlarından sadece Kawasaki hastalığı FDA tarafından onaylanmıştır. Başarıı tedavi sonuçları ve diğer alternatif ajanlara kıyasla daha güvenli olması nedeni ile özellikle toksik epidermal nekroliz, pemfigus ve pemfigoid grubu otoimmun büllü hastalıkların tedavisinde oldukça önemli bir seçenektir36-39.

iviG immunmodülatör etkisini, patolojik otoantikorları azaltma, T hücre aktivasyonunu engelleme, kompleman aracilı hasarı bloke etme, inflamatuar sitokinlerin üretim ve salınımını engelleme, dendritik hücrelerin farklılaşması ve gelişimini engelleme, kortikosteroidlere karşı hassasiyeti artırma, tromboksan A2 ve endotelini inhibe etme ve prostasiklin salınımını artırma gibi çeşitli mekanizmalar ile gösterir 40,41. Ayrıca IViG, toksik epidermal nekrolizin patogenezinde yer alan, keratinositlerin apopitozundan sorumlu, keratinosit yüzeyinde yerleşik Fas (CD95,Apo-1) ve Fas ligand (Fas L,CD95L)'ın birbirine bağlanmalarını, Fas reseptörünü bağlayarak engeller. Bu mekanizma sayesinde toksik epidermal nekroliz hastalarında ayrışmanın ilerlemesini durdurur42. Infüzyon aracılı yan etkileri hastaların \%10'undan daha azında görülürken genelde hafif ve kendini sınırlayan niteliktedir. Bu yan etkiler, baş ağrısı, kas ağrısı, flushing atakları, ateş, üşüme, titreme, yorgunluk, mide bulantısı, kusma, göğüste huzursuzluk, yüksek ya da düşük kan basıncı, taşikardi ve deri döküntüsü şeklindedir. İnfüzyon öncesi asetaminofen, non-steroid antiinflamatuarlar, antihistaminikler ya da kortikosteroidler gibi ilaçların kullanımı bu yan etkilerin ortaya çıkmasını azaltabilir43. Kas ağrısı, üşüme, titreme ve göğüste huzursuzluk hissi infüzyonun ilk bir saatinde gelişebilmekte ve infüzyona yarım saat kadar ara verilip daha sonra daha yavaş olarak devam edildiğinde genellikle hastalar rahatlamaktadır. Yorgunluk, ateş ya da mide bulantısı gibi şikayetler infüzyon sonrasında da gelişebilmekte ve 24 saate kadar devam edebilmektedir. Deri lezyonları ekzematöz döküntüler, ürtiker, likenoid reaksiyonlar, kaşıntı ve peteşi şeklinde bildirilmiştir44,45. Daha nadir görülen ama daha şiddetli yan etkiler tromboembolik olaylar, hemolitik anemi, akut akciğer hasarı, aseptik menenjit, anafilaksi ve renal tubuler nekroz şeklindedir30,46. Her kan ürününde olduğu gibi iviG tedavisi ile de enfeksiyon bulaşma riski vardır. 1990'ı ııllarda Amerika'da hepatit $C$ virüsü bulaşlarının bildirilmesi üzerine FDA tarafından konulan sıkı kurallar sonrasında efektif ve birbirini tamamlayıcı, farklı patojen uzaklaştırma yöntemleri uygulanmıştır. Bu şekilde, bilinen ya da bilinmeyen patojenlerden bu ürünlerin güvenli bir şekilde arındırıldığı kabul edilmektedir 47,48 .

\section{interferon}

Interferonlar, alfa $(\alpha)$, beta $(\beta)$, gamma $(\gamma)$ olmak üzere üç temel tipi olan sitokinlerdir. $\alpha$-interferon lökositlerden, beta-interferon fibroblastlardan ve gamma-interferon immun sistem hücrelerinden köken alır. Bu üç tip interferonun antiviral ve antiproliferatif etkileri benzerdir, ancak, immunmodulatuar özellikleri farklılık gösterir30. Etkili olabilmeleri için hedef hücrenin yüzeyindeki belirli reseptörlere bağlanmaları gerekir. $\alpha$ ve $\beta$ interferon aynı reseptöre bağlanırken, $\gamma$ farklı bir reseptöre bağlanır. Antiviral etkinliklerini, 2'-5'A sentetazı, ribonükleaz L'i ve protein kinaz P1'i indükleyerek gösterirler. 2'-5'A sentetazı indükleme, çeşitli büyüme faktörlerini inhibe etme, p53 tümör baskılayıcı genin ekspresyonunu artırma ve c-myc, c-fos ve c-ras onkogenlerinin ekspresyonunu baskılama yoluyla antiproliferatif etkinlik gösterirler30. Sınıf 1 ve 2 MHC 
antijenlerini uyararak, doğal öldürücü (NK) hücrelerin sayısını artırarak ve Th2 lenfositlerden IL-4, IL-5 ve IL-6 gibi sitokinlerin salgılanmasını engelleyerek immunmodülasyon yaparlar49. Interferon alfanın (alfa$2 a=$ Roferon $A \AA$, alfa-2b=intron $A \AA$ ) HIV ile ilişkili Kaposi sarkomu tedavisinde FDA onayı varken, interferon-alfa 2 b'nin ek olarak anogenital siğillerde de FDA onayı bulunmaktadır. İnterferonlar çoğu endikasyonda ruhsatsız olmalarına rağmen dermatolojide birçok hastalıkta başarıyla kullanılmaktadır. Bu hastalıkların başlıcaları Kaposi sarkomu( HIV ile ilişkili ya da değil), kutanöz T hücreli lenfoma, keratoakantom, skuamöz hücreli karsinom, bazal hücreli karsinom, hemanjiomlar, malin melanom ve viral siğillerdir30. Ayrıca aktinik keratoz, mastositoz, anjiosarkom, keloid, varisella zoster ve HSV enfeksiyonları, leyişmanya, skleroderma, lupus, Behçet hastalığı gibi hastalıklarda da başarıyla kullanımlarını bildiren yayınlar mevcuttur50-52. Yaygın ve sistemik hastalıklarda değişen dozlarda subkutan ya da intramusküler enjeksiyonlar yapılırken sınırlı hastalıkta lezyon içine enjeksiyon daha çok tercih edilir. İnterferon alfa enjeksiyonlarının sık görülen yan etkileri grip benzeri semptomlar (ateş, kas ağrısı, eklem ağrısı, yorgunluk, üşüme ve titreme), iştahsızlık, baş ağrısı, mide bulantısı, kusma, diyare, uyku düzensizliği, saçlarda incelme, enjeksiyon bölgesi reaksiyonları, hipotiroidi, hipertiroidi ve hiperglisemidir. Geçici kemik iliği baskılanması, hepatik enzimlerde geçici yükselme (genellikle tedaviden 2-5 gün sonra normale döner), parestezi, güçsüzlük, konuşma bozukluğu, kısa süreli hafızada bozulma, psikiyatrik bozukluklar (depresyon ya da intihara eğilim), sarkoidoz, akciğerlerde infiltrasyon, böbrek yetmezliği, pankreatit, ölümcül olabilen gastrik hemoraji ve çeşitli otoimmun hastalıklar, retinal hemorajiler ve retinal arter veya vende tıkanmalar çok daha nadir görülen yan etkileri arasındadır 30 . Interferon beta ve gammanın da benzer yan etkileri bulunmakla birlikte, bunlara ek olarak, interferon gamma tedavisiyle artmış serum trigliserid seviyeleri gözlenebilir 30 .

\section{Rituksimab}

B-lenfosit reseptörü CD20'ye bağlanan, IgG1 alt tipinde, şimerik fareinsan monoklonal antikorudur. B lenfositlerini baskılama tedavisinde kullanılır. 1997 yllında CD20+ B hücreli lenfoma tedavisi için onay almıştır. CD20, B hücrelerine spesifik bir yüzey antijenidir, öncü B hücreleri ve gelişmiş $B$ hücrelerin yüzeyinde eksprese olurken plazma hücreleri ve kök hücrelerin yüzeyinde eksprese olmaz53. Bu nedenle, rituksimab, plazma hücreleri ve prekürsör hematopoetik hücrelerde etkili olamaz. Sonuç olarak rituksimab tedavisi ile immunglobulin seviyeleri dramatik olarak düşmez ve tipik olarak tedavinin 6. ayında B hücreleri dolaşıma tekrar katılmış olur54. Rituksimab, CD20+ B lenfositleri, doğrudan antikorların hücrelere bağlanması ile, hücre aracılı sitotoksisiteyi uyararak ve apopitozu indükleyerek hasarlar. Rituksimab ayrıca B lenfositlerin yüzeyindeki CD40 ve CD80 ile etkileşime girerek, B ve T lenfositler arasındaki sinyalizasyonu bozar. Monosit ve makrofajlardan IL-10 salınımını artıııken, TNF- $\alpha$ salınımını azaltır. Rituksimab birkaç farklı yoldan immun sistemi modüle eder. Rituksimab ile ciddi yan etkiler oldukça nadir görülmektedir. Genellikle sadece ilk infüzyonda ortaya çıkan infüzyonla ilişkili yan etkiler en sık gözlenen yan etkisidir53. Pemfigus grubu hastalıklarda kullanımında çok az sayıda pnömoni, septik artrit, sepsis, ölümcül Pneumocystis carinii gibi ciddi enfeksiyonlar bildirilmiş̧ir53. Rituksimab, malin B hücrelerinde baskılanmaya neden oldugu gibi normal B hücrelerini de baskıladığından otoimmun hastalıklarda da kullanımıyla ilgili birçok çalışma mevcuttur55. Bu çalışmalarda romatoid artrit ve sistemik lupus eritematozus tedavisinde başarılı sonuçlar elde edilmiştir53. 2006 yılında romatoid artrit tedavisinde onay almıştır. Dermatolojik endikasyonlarda henüz onayı bulunmamasına karşın pemfigus vulgaris, paraneoplastik pemfigus, edinsel epidermolizis bülloza, kutanöz B hücreli lenfoma, dermatomiyozit, graft versus host hastalığında başarılı sonuçların bildirildiği olgu raporları mevcuttur 55 . Dermatoloji alanında pemfigus grubu hastalıklarda kullanımı daha ön plandadır.

\section{Omalizumab}

Omalizumab, immunglobulin E ( $\mathrm{g} \mathrm{E})^{\prime}$ nin Fc reseptörünü bloke eden insan rekombinant monoklonal antikorudur. Omalizumab serum $\lg$ E seviyelerini düşürür ve IgE' nin mast hücrelerine ve diğer immun sistem hücrelerine bağlanmasını engeller. Omalizumabın ciddi astım tedavisinde FDA onayı mevcuttur53. Dermatolojide henüz ruhsatlandırılmamış olmasına karşın etki mekanizması ve olgu serilerinde bildirilen başarıı sonuçlar göz önünde bulundurulduğunda atopik dermatit tedavisinde kullanımı ön plana çıkmıştır56. Tedaviye dirençli, IgE yüksekliği ile giden atopik dermatit tedavisinde önerilen bir tedavi olarak rehberlerde yerini almıştır. Ayrıca randomize kontrollü çalışmalarda omalizumabın antihistaminiklere dirençli kronik ürtikerde tedavi başarısı gösterildiğinden, kronik ürtiker tedavisinde 4. basamakta önerilen bir tedavi seçeneğidir. Yan etkiler açısından da oldukça güvenli olan bu ajanın dermatolojide IgE yüksekliği gözlenebilen diğer hastalıkların tedavisinde kullanılabileceği şeklinde yorumlar mevcuttur57.

\section{İmiquimod}

İmiquimod, güçlü antiviral ve antitümör etkinliği gösterilmiş immun cevabı modifiye edici bir ajandır. İmiquimod, interferon- $\alpha$, IL-2, IL-12 ve diğer sitokinlerin üretimini arttırarak immun sistemi uyarır. İmmun sistemin patojenleri tanımasını sağlayan Toll-benzeri reseptörlerden (TLR) biri olan TLR-7 üzerinden etki ederek monosit, makrofaj ve dendritik hücrelerden sitokin salınımına neden olur58. Imiquimoda benzer mekanizma ile TLR-7 ve TRL-8 reseptörlerini uyaran ve benzer etkinliği olan resiquimod ile de çalışmalar devam etmektedir58.

Imiquimod piyasada \%5 krem şeklinde bulunmaktadır. Anogenital siğil ve yüzeysel bazal hücreli karsinomun yerel tedavisinde onaylıdır. Ayrıca bazal hücreli karsinomun diğer tiplerinde, skuamöz hücreli karsinom, aktinik keratoz, bowen hastalığı, keratoakantom, kutanöz T hücreli lenfoma, meme dışı Paget hastalığı, lentigo maligna, melanom metastazları, basit viral siğiller, molluskum kontagiozum, herpes enfeksiyonları, keloid ve hemanjiom tedavilerinde de yeri olan bir ajandır58.

\section{Ekstrakorporeal fotoferez}

Ekstrakorporeal fotoferezde, periferik damardan alınan kandan aferez yöntemi ile toplanan mononükleer hücreler psoralen ile inkübe edildikten sonra $1 \mathrm{~J} / \mathrm{cm}^{2}$ dozunda ultraviyole A (UVA) ile ışınlanır. UVA ile ışınlanmış hücreler tekrar hastaya verilir59. UVA, lenfositlerde DNA hasarına yol açarak zararlı T-lenfositlerinin hasarlanmasını sağlar60 Dermatolojide evre 2-4 kutanöz T hücreli lenfoma tedavisinde 30 yıldır kronik graft versus host hastalığı tedavisinde 20 yıldır kullanılmaktadır59. Akut graft versus host hastalığı, Crohn hastalığı, sistemik skleroz gibi kollajen doku hastalıkları ve otoimmun büllü hastalıklarda da başarılla kullanıldığını bildiren yayınlar mevcuttur60. Etkili ve yan etkiler açısından güvenli bir tedavi seçeneği olan ekstrakorporeal fotoferezin kullanımını sınırlayan en önemli engel, yüksek maliyetidir. Klasik tedavilere dirençli ya da bunları kullanamayan seçilmiş hastalarda tedavi planında yer alan bir yöntemdir. 


\section{Diğer aferez yöntemleri}

Plazmaferez, immunadsorbsiyon gibi kanın belli elemanlarının çeşitli yöntemler ile ayıklandığı tedavi modaliteleri özellikle otoimmun hastalıkların tedavisinde denenmiş ve başarılı sonuçlar bildirilmiştir61. Kanda bulunan çeşitli antikorların spesifik immun bağlayııılar aracılığı ile uzaklaştırılığı immunadsorbsiyon ile pemfigus ve pemfigoid grubu hastalıklarda başarıı tedavi sonuçları elde edilmiştir61. Tedavilere dirençli otoimmun hastalıklarda ülkemizde sınırlı sayıda merkezde bu tedavi yöntemleri uygulanabilmektedir.

\section{Diğer immunstimulanlar}

Antihelmintik bir tedavi olan levamizol, H2 antagonisti olan simetidin, $\beta$-glukan, çinko gibi çeşitli elementler, $A, E$ ve $C$ vitamini gibi çeşitli vitaminler immun sistemi uyararak, çeşitli patogenizmalara sahip hastalıkların iyileştirilmesinde destek tedavisi olarak kullanılmışlardır62. Dermatolojide inatçı yaygın viral siğiller ve molluskum kontagiyosum gibi hastalıklarda iyileşmeyi hızlandırmak amacı ile immun sistemi uyarıcı ajanlar tedavi protokollerine eklenebilmektedir. Bu ajanların tedavi başarısını artırdığını gösteren çift-kör, plasebo kontrollü çalışmalar mevcut değildir.

\section{Kaynaklar}

1. Meggitt SJ, Anstey AV, Mohd Mustapa MF, Reynolds NJ, Wakelin S: British Association of Dermatologists' guidelines for the safe and effective prescribing of azathioprine 2011. Br J Dermatol 2011;165:711-34.

2. Schiavo AL, Puca RV, Ruocco V, Ruocco E: Adjuvant drugs in autoimmune bullous diseases, efficacy versus safety: facts and controversies. Clin Dermatol 2010;28:337-43

3. Meurer M: Immunosuppressive therapy for autoimmune bullous diseases. Clin Dermatol 2012;30:78-83

4. Newman WG, Payne K, Tricker K,et al. A pragmatic randomised controlled trial of thiopurine methyltransferase genotyping prior to azathioprine treatment: the TARGET study. Pharmacogenomics 2011;12:815-26.

5. Wang L, Weinshilboum R: Thiopurine S-methyltransferase pharmacogenetics: insights, challenges and future directions. Oncogene 2006;25:1629-38.

6. Anstey ACV, Wakelin S, Reynolds NJ. Guidelines for prescribing azathioprine in dermatology. Br J Dermatol 2004;151:1123-32.

7. Nunley JR, Wolverton S, Darst M: Systemic drugs. Dermatology. Ed. Bolognia JL, Jorizzo JL, Rapini RP. 2nd edition. Spain, Mosby Elsevier 2008;2005-20.

8. Nashel DJ: Mechanisms of action and clinical applications of cytotoxic drugs in rheumatic disorders. Med Clin North Am 1985;69:817-40.

9. Orvis AK, Wesson SK, Breza TS,et al. Mycophenolate mofetil in dermatology. J Am Acad Dermatol 2009;60:183-99.

10. Surjushe A, Saple DG: Mycophenolate mofetil. Indian J Dermatol Venereol Leprol 2008;74:180-4.

11. Mydlarski PR: Mycophenolate mofetil: a dermatologic perspective. Skin Therapy Lett 2005;10:1-6.

12. Allison AC, Eugui EM: Purine metabolism and immunosuppressive effects of mycophenolate mofetil (MMF). Clin Transplant 1996;10:77-84.

13. Amor KT, Ryan C, Menter A: The use of cyclosporine in dermatology: Part I. J Am Acad Dermatol 2010;63:925-46.

14. Gupta AK, Baadsgaard O, Ellis CN, Voorhees JJ, Cooper KD: Lymphocytes and macrophages of the epidermis and dermis in lesional psoriatic skin, but not epidermal Langerhans cells, are depleted by treatment with cyclosporine A. Arch Dermatol Res 1989;281:219-26.

15. Stellato $C$, dePaulis A, Ciccarelli A: Anti-inflammatory effect of cyclosporine A on human skin mast cells. J Invest Dermatol 1992;98:800-4.

16. Atakan N, Erdem C: The efficacy, tolerability and safety of a new oral formulation of Sandimmun-Sandimmun Neoral in severe refractory atopic dermatitis. J Eur Acad Dermatol Venereol 1998;11:240-6.

17. Kaplan AP: What to do with refractory urticaria patients. Curr Allergy Asthma Rep 2011;11:189-91

18. Hench PS, Kendall EC, Slocumb CH, Polley HF: Effects of cortisone acetate and pituitary ACTH on rheumatoid arthritis, rheumatic fever, and certain other conditions. Arch Intern Med 1950;85:545-666
19. Jackson S, Gilchrist H, Nesbitt LT Jr: Update on the dermatologic use of systemic glucocorticosteroids. Dermatol Therapy 2007;20:187-205.

20. Fauci AS, Dale DC, Balow JE: Glucocorticosteroid therapy: mechanisms of action and clinical considerations. An Intern Med 1976;84:304-15.

21. Barnes PJ, Pedersen S, Busse WM: Efficacy and safety of inhaled corticosteroids. Am J Respir Crit Care Med 1998;157:1-53.

22. Wollenberg A, Sharma S, von Buhnoff D, von Bubnoff D, Geiger E, Haberstok J, Bieber T: Topical tacrolimus (FK506) leads to profound phenotyping and functional alterations of epidermal antigen-presenting dendritic cells in atopic dermatitis. J Allergy Clin Immunol 2001:107:519-25.

23. de Paulis A, Stellato C, Cirillo R, Ciccarelli,et al. Anti-inflammatory effect of FK-506 on human skin mast cells. J Invest Dermatol 1992:99:723-8.

24. Spergel JM: Immunology and treatment of atopic dermatitis. Am J Clin Dermatol 2008:9:233-44

25. Hönigsmann $\mathrm{H}$ : History of phototherapy in dermatology. Photochem Photobiol Sci 2013;12:16-21.

26. Schwarz T, Schwarz A: Molecular mechanisms of ultraviolet radiationinduced immunosuppression. Eur J Cell Biol 2011;90:560-64

27. Elmets CA, Bergstresser PR, Tigelaar RE, Wood PJ, Streilein JW: Analysis of the mechanism of unresponsiveness produced by haptens painted on skin exposed to low dose ultraviolet radiation. J Exp Med 1983;158:781-94.

28. Schwarz T: 25 years of UV-induced immunosuppression mediated by T cellsfrom disregarded $T$ suppressor cells to highly respected regulatory $T$ cells. Photochem Photobiol 2008:84:10-18.

29. Kripke ML, Cox PA, Alas LG, Yarosh DB: Pyrimidine dimers in DNA initiate systemic immunosuppression in UV-irradiated mice. Proc Natl Acad Sci USA 1992;89:7516-20.

30. Smith D, Swamy PM, Heffernan M: Off-label uses of biologics in dermatology: Interferon and intravenous immunoglobulin (part 1 of 2). Am Acad Dermatol 2007;56:1-54

31. Wickramasinghe $\mathrm{L}$, Hindson TC, Wacks $\mathrm{H}$ : Treatment of neoplastic skin lesions with intralesional interferon. J AmAcad Dermatol 1989;20:71-4.

32. Levin $\mathrm{S}, \mathrm{Hahn} \mathrm{T}$, Rosenberg $\mathrm{H}$, Bino $\mathrm{T}$ : Treatment of life-threatening viral infections with interferon alpha: pharmacokinetic studies in a clinical trial. Isr J Med Sci 1982;18:439-46.

33. Kotter I, Eckstein AK, Stubiger N, Zierhut M: Treatment of ocular symptoms of Behcet's disease with interferon alpha2a: a pilot study. Br J Ophthalmol 1998:82:488-94.

34. Kazatchkine MD, Kaveri SV: Immunomodulation of autoimmune and inflammatory diseases with intravenous immune globulin. N Engl J Med 2001;345:747-55

35. Al-Mayouf SM, Laxer RM, Schneider R, Silverman ED, Feldman BM: Intravenous immunoglobulin therapy for juvenile dermatomyositis: efficacy and safety. J Rheumatol 2000;27:2498-503.

36. Ahmed AR: Intravenous immunoglobulin therapy for patients with bullous pemphigoid unresponsive to conventional immunosuppressive treatment. J Am Acad Dermatol 2001:45:825-35.

37. Harman KE, Black MM: High-dose intravenous immune globulin for the treatment of autoimmune blistering diseases: an evaluation of its use in 14 cases. Br J Dermatol 1999;140:865-74.

38. Kim KJ, Lee DP, Suh HS,et al. Toxic epidermal necrolysis: analysis of clinical course and SCORTEN-based comparison of mortality rate and treatment modalities in Korean patients. Acta Derm Venereol 2005;85: 497-502.

39. Sami N, Letko E, Androudi S, Daoud Y, Foster CS, Ahmed AR: Intravenous immunoglobulin therapy in patients with ocular cicatricial pemphigoid: a long-term follow-up. Ophthalmology 2004;111:1380-2.

40. Rossi F, Kazatchkine: Antiidiotypes against autoantibodies in pooled normal human polyspecific Ig. J Immunol 1989;143:4104-9.

41. Bayry J, Lacroix-Desmazes S, Carbonneil C,et al. Inhibition of maturation and function of dendritic cells by intravenous immunoglobulin. Blood 2003:101:758-65

42. French LE, Prins C: Erythema Multiforme, Stevens-Johnson Syndrome and Toxic Epidermal Necrolysis. Dermatology. Ed. Bolognia JL, Jorizzo JL, Rapini RP. 2nd edition. Spain, Mosby Elsevier, 2008;287-300

43. Dalakas MC: The use of intravenous immunoglobulin in the treatment of autoimmune neuromuscular diseases: evidence-based indications and safety profile. Pharmacol Ther 2004;102:177-93.

44. Dwyer JM: Manipulating the immune system with immune globulin. N Engl J Med 1992;326:107-11.

45. Vecchietti G, Kerl K, Prins C,et al. Severe eczematous skin reaction after high-dose intravenous immunoglobulin infusion: report of 4 cases and review of the literature. Arch Dermatol 2006;142:213-7. 
46. Berkovitch M, Dolinski G, Tauber T, Aladjem M, Kaplinsky C: Neutropenia as a complication of intravenous immunoglobulin (IVIG) therapy in children with immune thrombocytopenic purpura: common and non-alarming. Int J Immunopharmacol 1999;21:411-5.

47. Dahl MV, Bridges AG: Intravenous immune globulin: fighting antibodies with antibodies. J Am Acad Dermatol 2001;45:775-83.

48. Sati HI, Ahya R, Watson HG: Incidence and associations of acute renal failure complicating high-dose intravenous immunoglobulin therapy. $\mathrm{Br} \mathrm{J}$ Haematol 2001;113:556-7.

49. De Andrea M, Ravera R, Gioia D, Gariglio M, Landolfo S: The interferon system: an overview. Eur J Paediatr Neurol 2002;(Suppl):55-8.

50. Vancheeswaran R, Black CM: Alpha interferon-2a (Roferon-A) in the treatment of diffuse cutaneous systemic sclerosis: a pilot study. UK Systemic Sclerosis Study Group. Br J Rheumatol 1992;31:683-9.

51. Arnaudova P, Rashkov R, Tsanev R: Application of interferon-gamma containing gel for local treatment of skin ulcers in autoimmune vasculitides and skin changes in progressive systemic sclerosis. J Rheumatol 1993;20:1445-6.

52. Alpsoy E, Durusoy C, Yilmaz E,et al. Interferon alfa-2a in the treatment of Behcet disease: a randomized placebo-controlled and double-blind study. Arch Dermatol 2002;138:467-71.
53. Graves JE, Nunley K, Heffernan M: Off-label uses of biologics in dermatology: Rituximab, omalizumab, infliximab, etanercept, adalimumab, efalizumab, and alefacept (Part 2 of 2). J Am Acad Dermatol 2007:56:55-79.

54. Grillo-Lopez A:. Rituximab: an insider's historical perspective. Semin Oncol 2000;27(Suppl):9-16.

55. Espana A, Ornilla E, Panizoc C: Rituximab in dermatology. Actas Dermosifiliogr 2013;104:380-92.

56. Krathen RA, Hsu S. Failure of omalizumab for treatment of severe adult atopic dermatitis. J Am Acad Dermatol 2005;53:338-40.

57. Altman MC, Naimi DR: Omalizumab for chronic urticaria. N Engl J Med 2013; 368:2528-30.

58. Eedy DJ: Imiquimod: a potential role in dermatology?. $\mathrm{Br} J$ Dermatol 2002:147:1-6.

59. Adışen E, Gürer MA: Ekstrakorporeal fotoferez. Etki mekanizması, yan etkileri, dermatolojik endikasyonları. Türkderm 2008;42:39-44.

60. Worel N, Leitner G: Clinical results of extracorporeal photopheresis. Transfus Med Hemother 2012;39:254-262.

61. Meyersburg D, Schmidt E, Kasperkiewicz M: Immunoadsoption in dermatology. Therapeutic Apheresis and Dialysis 2012;16:311-320.

62. Galeotti M: Some aspects of the application of immunostimulants and a critical review of methods for their evaluation. J Appl Ichthyol 1998;14:189-199. 